\title{
A study on the basic path for producer services to promote industrial upgrading and the related finance and taxation measures
}

\author{
Jiechang Xia ${ }^{*}$ and Xiaobing Zhang
}

\author{
* Correspondence: \\ xiajiechang@126.com \\ National Academy of Economic \\ Strategy, Chinese Academy of Social \\ Sciences, Beijing 100836, China
}

\begin{abstract}
Accelerating the development of producer services is both conducive to enhancing the level and quality of industrialization, promoting industrial upgrading, and the only way to realize a modernized and high-end service industry, thus a 'win-win' strategic choice for China. In the process of its industrialization and urbanization, China must follow a development path driven by the two engines of producer services and modern manufacturing. China should reinforce the roles played by producer services in penetrating and supporting manufacturing and agriculture amid the development of industrial division, integration, and agglomeration, enhancing the level of producer services and realizing the development of producer services. The government and market are the two basic forces in promoting the development of producer services. We should both fully recognize the fundamental role that the market mechanism plays, as well as make great efforts to give full play to the positive roles of the government policy, especially finance and taxation policies, in promoting producer services.
\end{abstract}

Keywords: Industrialization process; Producer services; Industrial upgrading; Finance and taxation policy

How to boost industrial upgrading, and by what path and strategy, has become a hot issue in academic and policy-making circles in recent years. Li Keqiang, vice premier of the State Council, emphasized in the national development and reform symposium, 'The strongest industrial support for expanding domestic demand is the service industry. We should, when actively developing the hi-tech industry and the advanced manufacturing industry, place the strategic emphasis of our adjustment to the industrial structure on developing the service industry, improving the policy support system, increasing the proportion of the service industry and enhancing the level of the service industry, and promoting the integrated development of the service sector and industry.' Li's speech provides a clear direction for the transformation and upgrading of the industrial structure, that is, promoting the transformation and upgrading of the industrial structure by means of integrating the service sector and industry as well as boosting the development of the service industry.

(c) 2014 Xia and Zhang; licensee Springer. This is an Open Access article distributed under the terms of the Creative Commons Attribution License (http://creativecommons.org/licenses/by/2.0), which permits unrestricted use, distribution, and reproduction in any medium, provided the original work is properly cited. 


\section{The significance of promoting industrial upgrading by means of producer services}

The basic meanings of producer services and industrial upgrading

Producer services refer to the service industry, which provides, directly or indirectly, intermediate services for the production or service process, and the service industry, which caters to companies or production activities. It has the basic features of containing high added value, high knowledge content, and a high degree of human capital and agglomeration. Producer services primarily include transportation, modern logistics, banking and insurance, research and development, industrial design, management consulting, business service, human resource service, testing and certification services, and legal services. Industrial upgrading refers mainly to the improvement of the industrial structure and the enhancement of industrial quality and efficiency. We can analyze the contents and forms of industrial upgrading from multiple perspectives: first, it refers to extending to the areas with high-technology content and high added value along the industrial chain; second, it refers to the replacement and upgrading of product technology; third, it refers to creating new industries. Among the three forms of industrial upgrading mentioned above, the most important and the most urgent one for Chinese enterprises is to realize the upgrading of the industrial chain, for they have long been in the low end of manufacturing process in the international division of labor. For example, nearly all Barbie toys are currently manufactured in China, but the processing fee the Chinese enterprises earn for each piece is only US $\$ 0.35$, while the US company possessing the intellectual rights and brand receives US\$7.9 (Chen 2011).

\section{The significance of promoting industrial upgrading by means of producer services}

(1) In the middle and late stages of industrialization, producer services have become the main support for industrial upgrading. China has entered the new phase of accelerated development in the middle and late stages of industrialization. However, there exist serious debates concerning the direction of transformation and upgrading of the industrial structure after this phase. Some scholars maintain that the transformation and upgrading of the industrial structure must rely on vigorously developing producer services, for they are not only the most important support for industrial transformation and upgrading but also the major carriers for labor transfer. Vigorously developing the modern service industry, primarily in the form of producer services, is the most important way to solve the problem of labor transfer. But some scholars say that industrial upgrading should still be based on heavy industry and the chemicals industry, and in the process of China's industrialization, China should not overemphasize increasing the proportion of the service industry in the national economy. Developing heavy industry and the chemical industry and renovating and upgrading the traditional manufacturing industry are still major tasks faced by China. The authors of this paper hold that the former opinion better suits China's situation and the objective laws in the process of industrialization, because vigorously developing producer services is more helpful to resolving various conflicts in the process of transforming China's economic development model. For example, there is an inconsistency between growth and employment, and employment elasticity in the service industry is 
obviously higher than that in manufacturing. The number of jobs created by unit capital invested in service industry is about 2.5 times that of heavy industry and the chemicals industry. In addition, the service industry's demand for resources and energy is also much lower than that from manufacturing, with the service industry using only $25 \%$ of the resources and energy of the manufacturing industry to create GDP of 10,000 yuan (Li 2012), which better meets the requirements of sustainable development.

(2) Vigorously developing producer services is an important way to solve the 'chronic and stubborn disease' of China's manufacturing being big but not strong. 'Made in China' has arisen rapidly and become an indispensable part of the global economy, directly affecting global activity. In 2011, China' secondary industry realized an added value of 22.1 trillion yuan, accounting for $46.8 \%$ of the GDP, and calculated by the year-end exchange rate, it amounted to US\$3.5 trillion; while the added value of US manufacturing was US\$18.4 trillion, accounting for $12.2 \%$ of GDP. Seen from the data over the years, the proportion of the added value of China's manufacturing in that of secondary industry is about $70 \%$ (e.g., this proportion was $69.85 \%$ in 2009). Calculated using this data, we can estimate that the added value of China's manufacturing in 2011 was about 15.4 trillion yuan, US\$2.4 trillion which was 1.33 times that in the USA. However, we must recognize that China's manufacturing is mostly big but not strong, relying primarily on the advantage of low-cost labor, and succeeds by quantity. Most of China's manufacturing is in the low end of the industrial chain, which necessitates industrial transformation and upgrading. Producer service is an important driving force for its transformation and upgrade, which, by their strong support and penetration roles, can serve as a propeller of the growth of manufacturing and support for manufacturing's rise. Today, more and more countries and their companies see developing producer services as a way to enhance their industrial competitiveness and their control of the global economy, and they promote their industrial transformation and upgrading via producer services. At present, producer services, including mainly communications, logistics, and banking services, account for more than $50 \%$ of the overall service industry in developed countries such as the USA and Japan, and these countries are continuously strengthening the penetration and integration of producer services with other industries. Many well-known transnational corporations have transferred their main business from manufacturing to the service industry, and the proportion of services in sales and profits has been increasing. International experience shows that accelerating the development of producer services is both conducive to enhancing the level and quality of industrialization and promoting industrial upgrading, the only way to realize a modernized and high-end service industry, and is a 'win-win' strategic choice for China.

\section{Division, integration, and agglomeration: the basic path of promoting industrial upgrading through producer services}

Deepening industrial division and cooperation, following the path of development driven by the two forces of modern manufacturing and producer services

China is in the phase of accelerated development in the middle and late stages of industrialization. As seen from the international experience, countries generally follow 
a development path that is driven by two factors, modern manufacturing and producer services, which are integrated with each other. This means that China can neither follow the old route of relying on traditional manufacturing and heavy industry and the chemicals industry, nor develop producer services separated from industry. Instead, China should select the strategy of development driven by both modern manufacturing and producer services along with their division and interaction and should especially focus on the 'entity economy' of manufacturing to vigorously develop producer services, embedding high-end service elements solidly into manufacturing and promoting the transformation and upgrading of manufacturing as well as enhancing its competitiveness by producer services. China has a large manufacturing industry. With the enhancement of manufacturing's development level and degree of specialization, there exists a requirement for separating producer services from manufacturing. The key to establishing the service economy is to make corresponding policies, create a favorable environment, and enable manufacturing companies to have the incentive and capability to separate producer services. An important way to achieve this strategic goal is to refine the division of labor based on specialization, encourage the service segment of manufacturing enterprises to be hived off, and facilitate business outsourcing, i.e., manufacturing enterprises making a vertical decomposition of a series of producer services activities previously provided internally, outsourcing those activities such as $R \& D$, designing, internal transportation, and procurement to professional service providers. The biggest benefit of this type of division based on specialization is that it can enable each party to fully exert their own comparative advantages, realize the optimal allocation of resources and factors, expand market demand from other parties, and enhance the industry's development potential.

\section{Strengthening industrial integration and reinforcing the penetration and support of producer services for manufacturing and modern agriculture}

One important feature of the development of modern industry is industrial integration. In the world today, the relationships among the service industry, manufacturing, and modern agriculture have become tighter and tighter, all of which are gaining development by integrating and interacting with each other. In the system of modern industry, material production demands input from related producer services, and its development and expansion must rely on precursors including producer services, especially financial capital and human capital. Only through the coordination and interaction of advanced technology, R\&D, logistics, marketing, and other links can material production be transformed into material wealth. With the increasingly intensive and widespread employment of information technology, global manufacturing is changing from 'manufacturing based on physical material inputs' to 'manufacturing based on service inputs,' i.e., products manufactured are more and more 'soft' and 'individualized,' and producer services have become one of the most important inputs for manufacturing. Similarly, the service model cannot be realized and service activities cannot be fulfilled without manufacturing and manufactured goods, which are the material carriers. Services and products rely on each other to meet the demands of human beings. Therefore, the relationship between the service industry and manufacturing should be described as follows: they coexist with each other and share wealth and woe ( $\mathrm{Li}$ and Xia 2012). 
China is devoted to realizing new-style industrialization and promoting industrial upgrading. The most important way is to vigorously develop producer services and promote the integration and interactive development of producer services and manufacturing, which is a new emphasis of China's industrial policies and a strategic choice that must be adhered to over the long term. Similarly, development of modern agriculture cannot go without the support of the service industry. Efforts cannot be concentrated only on crop farming in developing modern agriculture; instead, China should build a complete chain containing the links involved before production, during production, and after production. Generally speaking, the links involved before production and after production basically belong to the scope of producer services. If more producer service elements are integrated into modern agriculture, China can both drive the modernization of agriculture by means of a modern service industry and broaden the space for the development of producer services, creating stronger market demand for producer services.

\section{Strengthening industrial agglomeration, establishing several agglomeration areas and functional parks for producer services, and promoting the upgrading of manufacturing by service industry clusters}

Development of industrial agglomeration is one important feature and the trend of producer services of which China should take advantage. Various levels of governments in China are now laying particular stress on the development of service industry agglomeration and establishing various types of service industry agglomeration areas. This model of agglomerating a large number of companies in the service industry and related institutes in a special area reflects the internal requirement of modern service industry development and determines, to some extent, the spreading influence and competitiveness of the industries in the city where the agglomeration area is located. Seen from the experience of manufacturing development both domestically and abroad, any areas with advanced producer services and a high level of agglomeration always have a relatively prosperous, more competitive manufacturing industry. Compared with the central and western regions of China, the southeastern coast areas of China do not possess an advantage in terms of resources. However, manufacturing in the southeastern coast areas is much more advanced than that in the central and western regions, which is due to the fact that the southeastern coastal areas have a sound producer services system and producer agglomeration areas and functional parks with a relatively high level of specialization. It is exactly this type of development of producer services agglomeration, through embedding knowledge-intensive producer services elements on a large scale, which drives the upgrading of manufacturing.

Geographic agglomeration of the service industry is an inevitable choice of the external economy, scale economy, and scope economy. However, China must guard against the development of agglomeration being trapped into the practice of 'agglomeration for the purpose of agglomerating, for agglomeration is only a means and not a goal. Taking the route of agglomeration development should avoid collecting companies in one region that seem to be interrelated but are not actually related to each other and cannot produce a synergistic effect. Real agglomeration is a group composed by companies related to each other: professional suppliers, service providers, firms related to the industry, related $R \& D$ institutes, and relevant industry associations, which are collected 
geographically. It is a phenomenon in which a large number of companies closely related to one industry and relevant supporting institutions gather together in one specific region and form a strong and continuous competitive advantage.

Taking the route of agglomeration development must guard against 'agglomeration in appearance but not in spirit.' Taking the route of agglomeration development should first respect the companies' freedom to choose, and avoid agglomeration by force. Second, governments should play the roles of leadership and guidance, strengthening their guidance in planning the construction of service agglomeration areas, taking seriously the construction of public information platforms, technical platforms, and significant communication infrastructure in the producer service agglomeration areas or functional parks, and establishing standards and evaluation systems for the agglomeration areas. China should bring the infrastructure construction of producer services functional parks into the budget and allot a certain portion of funds to support this construction. China should especially support the construction of a market for large-scale service products exchange and infrastructure for releasing service product information, thereby speeding up the development of service industry agglomeration.

It has been suggested that a national service industry guidance fund or a national special fund for service industry construction be used to foster, in regions with comparatively obvious advantages in manufacturing, several key producer service agglomeration areas or functional parks that possess strong capabilities for innovation, a good environment for starting businesses and prominent characteristics, incentivizing service resources to gather in these agglomeration areas and functional parks. The government should guide the formation of high-end producer services agglomeration areas with the leading enterprises functioning as the core and small and medium-sized enterprises developing collaboratively. China should, by the demonstration and guiding roles of these key agglomeration areas and function parks, establish the growth pole of high-end producer services, foster a new support for local economic growth, increase tax sources, and change the traditional method of simply relying excessively on industrial parks for driving regional development.

\section{Improving finance and taxation policies concerning the development of China's producer services}

Whether analyzed from size or quality of development, China's producer services are far behind those in developed countries and some developing countries. Boosting the development of producer services and implementing a strategy of prioritizing the development of producer services are both important and pressing tasks. Government and the market are two basic forces to promote the development of producer services. We should fully recognize the fundamental role played by the market mechanism and make great efforts to give full play to the positive roles played by government policies, especially finance and taxation policies, in promoting producer services.

\section{Financial investment should properly favor the service industry and guide other social capital to invest in producer services}

Development of China's producer services demands a significant amount of capital. Given the continuous increase of the national wealth, financial investment should properly favor producer services and guide other social capital to invest in the service 
industry. Of course, investment of financial capital in producer services must meet the requirements of public finance and the market economy, follow the principle of 'doing what is right, and refraining from doing what is wrong, give full play to the role of financial capital in 'achieving the great with little,' and focus on producer services in key areas, weak links, and areas with obvious externalities. Of course, it is not adequate to rely merely on government investment to develop the service industry, and we should gradually change the pattern of investment solely by government to investment by diversified sources including government, enterprises, individuals, and society. To this end, we should break the industry monopoly, lower the threshold, simplify formalities, and mobilize various social forces such as foreign capital and private capital to invest in producer services.

\section{Improving the government procurement system and promoting the development of} producer services

Compared with developed countries, the proportion of government procurement in China's GDP is comparatively low, and the structure of government procurement is fairly irrational, with the proportion of service products being still lower. Government procurement in Western developed countries usually accounts for 10\% of the GDP and $30 \%$ of the government spending. In China, government procurement in 2011 surpassed 1 trillion yuan, which amounted to only $2.13 \%$ of the GDP and $9.65 \%$ of government spending. The gap is obvious (Xia et al. 2012). Moreover, the structure of government procurement in China is quite irrational. Its major component is bidding for public works and the purchase of office supplies, and the proportion of service products is abnormally low. The government should enlarge the scale of procurement to a proper extent and expand to and favor engineering projects and especially service projects. Only by enlarging the scale of government procurement and setting restrictions to the procurement activities of government can the goals of implementing the government procurement system be achieved. Gradual improvement of the public finance system and budget system requires the continuous expansion of the scope of government procurement. We must change the previous pattern of emphasizing procurement of material products and downplaying that of service products, and include more service areas into the scope of government procurement, introducing the market competition mechanism, and making open, just and equitable bid invitations to service industries, so as to increase market demand for producer services.

\section{Employing finance and taxation policies to guide the upgrading of the internal structure of the service industry, promoting the development of a modernized and high-end service industry}

Most of the service industry has high knowledge content and high added value, and part of producer services have both the characters of knowledge intensiveness and labor intensiveness, which can satisfy the dual goals of industrial upgrading and employment in China, reflecting the major direction of modern industrial development. China should both give play to the comparative advantage of traditional labor-intensive service industry in order to alleviate the pressure of employment and prioritize, by means of finance and taxation policies, the development of high-end producer services, including banking and insurance, software and information, research and development, 
modern logistics, industrial designing, management and consulting, business service, testing and certification, and legal services, and optimize the internal structure of service industry to promote the modernization of the service industry. It has been suggested that China should, according to Notes on Relevant Taxation Policies for Enterprises in Service Industry with Advanced Technologies released by the Ministry of Finance, National Development and Reform Commission and State Administration of Taxation in 2009, categorize the service industry, clarifying that companies in the modern service industry with a high degree of knowledge intensiveness and technological content should refer to the management of high-tech enterprises and enjoy preferential taxation policies.

\section{Implementing finance and taxation policies conducive to the development of producer services agglomeration functional areas, giving play to the driving effects of service industry agglomeration for industrial upgrading}

As seen from the experience both domestically and abroad, the roles played by producer services for industrial upgrading are mainly realized in the form of 'agglomeration' or 'functional areas.' This is because only by the formation of agglomeration can the positive roles of the service industry's external economy, scope economy, and spillover of knowledge and technology be given full play in industrial upgrading. Therefore, we should make great efforts to increase the financial investment in agglomeration areas or functional parks for producer services and establish public information platforms, technical platforms, and key communication infrastructure for the modern service industry. China should bring infrastructure construction of producer services functional parks into the budget and allot a certain portion of the fund to support the infrastructure construction of the functional parks. China should especially support the construction of market for large-scale service products exchange and infrastructure for releasing service product information, speeding up the development of service industry agglomeration. It has been suggested that a national service industry guidance fund or a national special fund should be used to construct nation-level demonstration parks or functional areas of producer services, and through the demonstration and guidance roles of these function areas establish the growth pole of high-end producer services, so as to promote the upgrading of manufacturing in virtue of strong producer services.

Appropriate preferential taxation, support, and reward policies should be implemented for producer service agglomeration areas. For example, a certain amount of reward is given in some cities to service enterprises newly settled in the producer services agglomeration areas that are encouraged by the city and submit an annual tax surpassing a certain amount. For small- and medium-sized service enterprises newly settled in the producer services agglomeration areas that have difficulty paying taxes, land use tax, property taxes, and others are regularly reduced or exempted after the application is reported and approved according to the current taxation management authority. For key producer service projects newly constructed in agglomeration areas that do not divide and sell the property rights after the construction, the government awards a subsidy equal to $50 \%$ of the local retention of the sales tax and corporate income tax levied on the business and property rental within 2 years from the starting of the business. The policy support measures of these cities have effectively promoted the 
development of producer service agglomeration areas and functional parks, and driven the transformation and upgrading of manufacturing.

\section{Optimizing the structure of fiscal expenditure on education and training those who can} meet the diversified requirements of producer services

Producer services have the main features of having relatively high added value, involving high degree of expertise, and having various levels of human capital. Qualified professionals with high-end and practical knowledge and expertise in multiple areas are important prerequisites for the rapid development of producer services. Training and introducing high-quality professionals in producer services are the duty of government. China should reform the traditional methods of training professionals, emphasize the development of vocational education with particular characteristics, and support various higher education institutions, vocational education, and training agencies to carry out training of interdisciplinary and skilled professionals for the modern service industry. Based on the principle of 'not wishing to own, but wishing to utilize,' China should actively promote a new type of distribution model such as technology-based equity, management staff holding shares, and stock options, establish a mechanism for flexible personnel flow, and encourage more professionals in the high-end service industry to gather in China. Institutions of higher education are certainly the main force for training professionals, but this does not mean that higher education institutions should cultivate professionals solely with cutting-edge technologies and expertise. They also need to vigorously develop vocational education to train professionals applicable to producer services. Given the grim employment situation, especially serious structural unemployment, it is particularly important to train professional personnel with special skills. China should make an overall plan for fiscal education funds and treat vocational and technical education and higher education on an equal basis. China should give play to the guiding role of fiscal funds and preferential taxation, actively guide social capital to invest in vocational education, and promote the prosperity of vocational education. China should combine the income distribution reform and the social security system reform, provide a certain amount of subsidy to students from low-income families to study in vocational schools, channel the willingness of students to attend vocational schools, and enhance the employment capabilities and employment level of society.

Utilizing finance and taxation policies to improve the construction of information infrastructure, enhancing the level of information technology development to drive industrial upgrading

The speed, cost, and accessibility of information technology infrastructure are of great significance to producer services and industrial upgrading. Information technology infrastructure has obvious externalities and thus requires strong government support policies. All countries with advanced information technology infrastructure such as the USA, India, Ireland, and others have realized the substantial development of information technology infrastructure by way of strong national support policies. For China, support of the construction of information technology infrastructure on the part of finance and taxation policies can be provided in the following two aspects: (1) increasing the investment in the construction of information technology infrastructure, so as to enhance the speed of information transmission, increase network capacity, reduce 
usage costs, and solve problems related to compatibility and interactivity; (2) implementing the Notes on Several Policies to Further Encourage the Development of the Software Industry and the Integrated Circuit Industry issued by the State Council, work out standards to identify high-tech service enterprises in the information technology infrastructure area, and the Ministry of Science and Technology, the Ministry of Finance and State Administration of Taxation should make concrete stipulations on corporate R\&D investment, the proportion of income from high-tech products sales, and requirements of academic qualifications and professional titles of the employees. The government should ensure that companies engaged in the construction of information technology infrastructure can fully enjoy current preferential taxation policies, so as to attract social capital to invest more in the construction of information technology infrastructure.

\section{Actively and discreetly promoting the pilot work of changing the sales tax to an value-added tax for the modern service industry}

The modern service industry is an important component of the national economy, and accelerating the development of the modern service industry is an important way to expand domestic demand and transform the pattern of economic development. In general, the development of China's modern service industry is still at a low level, and current taxation system and policies are not conducive to its development. The pilot work of changing sales tax to a value-added tax (VAT) is of great importance to eliminating double taxation in the area of the modern service industry, reducing its tax burden, pushing manufacturing enterprises to voluntarily divest producer services, and increasing the supply of producer services. It is imperative to carry out the reform of changing sales tax to a VAT, but since the current VAT was designed based on the features of manufacturing, simple reproduction of it for the service industry on which sales tax is currently levied is obviously too simple, for there are fundamental differences between the process of production and the operation of the service industry and that of manufacturing. In manufacturing, production mainly relies on physical materials including raw materials, fuels, power, semimanufactures, and so on, and in the current VAT system, after the deductions are made, the object of taxation is basically the added value of products. However, in the service industry, a great deal of production and operation does not rely primarily on the consumption of materials, but on that of non-material human capital and intangible assets including 'taste,' 'originality', and so on (Gao 2012). If labor costs in the service industry cannot be deducted, it is possible that the burden of some modern service industries would be heavier than that before the reform, which obviously runs counter to the intent of the reform. For the purpose of encouraging the development of the modern service industry, it has been suggested that intangible assets, human capital, and so on be included in the scope of VAT deduction as early as possible. In addition, there is no explicit instruction in the reform plan of 'changing sales tax to VAT' for tax exemption of service exports. Taxes are levied on service products exported from China and compared with the service industry in countries where a VAT is levied on the service industry, the service industry in China is in a disadvantageous position in the international market. In order to strengthen the competitiveness of China's service industry in the international market, especially in the producer services trade, specific measures and rules for the implementation of exempting, deducting and reimbursing taxes levied on the service industry must be worked out as soon as possible. 
Competing interests

The authors declare that they have no competing interests.

\section{Authors' contributions}

JX conceived the framework and ideas of the entire study and wrote the first and second main sections of this article. $X Z$ wrote third main section. Both authors read and approved the final manuscript.

\section{Authors' information}

$J X$ is a research fellow and director of the research division for service economics and Prexy' Assistant of the National Academy of Economic Strategy, Chinese Academy of Social Sciences. He is also a professor and doctoral supervisor at the Graduate School of the Chinese Academy of Social Sciences. He primarily researches service economics theory and policy. He is also the academic leader of service economics, key discipline of Chinese Academy of Social Sciences, chief expert of the project 'Study on China's Modern Service Industry Development Strategy,' an important project sponsored by the National Social Science Fund, and the expert giving the report titled Promoting China's Great Development of Service Industry at the 26th lecture for Standing Committee of the National People's Congress. He has published nearly 100 articles in key journals, including Economic Research Journal, Management World, China Industrial Economics, Finance \& Trade Economics, and others. His representative works include Greeting the Era of Service Economy (Economy \& Management Publishing House 2010).

$\mathrm{XZ}$ is conducting his postdoctoral research in the field of applied economics at the National Academy of Economic Strategy, Chinese Academy of Social Sciences. His research interest lies primarily in industrial economy and industrial policy. He has published six papers in journals including the Journal of Graduate School of Chinese Academy of Social Sciences, Review of Economic Research, and others.

\section{Disclosure}

This paper is a periodical achievement of the project 'Study on the Regional Measures to Speed up the Development of Modern Service Industry in the Twelfth-Five-Year Plan Period,' sponsored by the National Social Science Fund (11CJY070), and the project 'Study on China's Strategy of Mid- and Long-term Service Economy Development,' listed in the Knowledge Innovation Project of Chinese Academy of Social Sciences.

Received: 31 December 2012 Accepted: 8 November 2013

Published: 3 January 2014

\section{References}

Chen Q (2011) Self-reliant Innovation and Industrial Upgrading (自主创新和产业升级). CITIC Press Corporation (中信出版社), Beijing

Gao P (2012) Self-restructuring in Expanding the Value-added Tax Base (增值税 “扩围” 中的自身重构). China Finance and Economic News (中国财经报), May 22, No. 6

Li J (2012) Ten Industries Urgently Awaiting Development for Promoting the Construction of Urbanization (推进城镇化建设亟待发展的十大产业). China Economic Times (中国经济时报), December 04, No. 4

Li W, Xia J (2012) Integration of Manufacturing and the Service Industry Based on Self-reliant Innovation: Mechanism and Path (基于自主创新的制造业与服务业融合: 机理与路径). Journal of Nanjing University (Philosophy, Humanities and Social Sciences) (南京大学学报). No.2

Xia J et al (2012) A study on the mechanism of finance \& taxation institutions of China's service industry development (我国服务业发展财税体制机制研究). Research Report, National Development and Reform Commission, Beijing

doi:10.1186/2196-5633-2-4

Cite this article as: Xia and Zhang: A study on the basic path for producer services to promote industrial upgrading and the related finance and taxation measures. China Finance and Economic Review 2014 2:4.

\section{Submit your manuscript to a SpringerOpen ${ }^{\circ}$ journal and benefit from:}

- Convenient online submission

- Rigorous peer review

- Immediate publication on acceptance

- Open access: articles freely available online

- High visibility within the field

- Retaining the copyright to your article

Submit your next manuscript at $\gg$ springeropen.com 